International Research Journal of Management, IT \& Social Sciences
Available online at https://sloap.org/journals/index.php/irjmis/
Vol. 5 No. 6, November 2018, pages: $1 \sim 8$
ISSN: 2395-7492
https://doi.org/10.21744/irjmis.v5n6.294

\title{
Villa Trading Contract with Right to Use on Timeshare Business Program in Bali
}

Ni Ketut Elly Sutrisni ${ }^{\text {a }}$

Article history:

Received: 5 July 2018

Accepted: 30 September 2018

Published: 1 October 2018

\section{Keywords:}

Business program;

Ownership;

Rights to use;

Timeshare;

Villa trading contract;

\begin{abstract}
Ownership of villas by Foreigners is possible with the right to use (RTU) not property rights. And Foreign Citizen is domiciled in Indonesia according to Government Regulation No. 40 on Right of Use, Right of Use and Right to Use. The sale and purchase of villa with use rights in the Time Share program is a formal agreement, meaning that for the legal villa sale agreement is not solely achieved by the agreement between seller and buyer concerning goods and price only (consensual), but by Law, the specified formality. As for what is meant by certain formalities in buying and selling villa is a necessity to be conducted notarial. In the contract of sale and purchase of villa with use rights in the Time Share program, the arrangement of Force Majeure is explicitly not regulated, but this must be expressly stipulated in the sale and purchase agreement. In the agreement stated that the owner or management will provide replacement accommodation and the management has also insured villas so that if the villa is destroyed due to unforeseen circumstances, the insurer will take over the risk of various dangers that may occur.
\end{abstract}

2395-7492 () Copyright 2018. The Author. This is an open-access article under the CC BY-SA license (https://creativecommons.org/licenses/by-sa/4.0/) All rights reserved.

\section{Author correspondence:}

Ni Ketut Elly Sutrisni,

Faculty of Law, National Education University, Denpasar, Bali, Indonesia

Email address: ellysutrisni@undiknas.ac.id

\section{Introduction}

Enjoying a holiday with or without travel agent is very commonly known around the world. Not only travel agency, one of the tourism areas that experienced great profits is a hotel, villa or lodging because tourists who take vacations usually need to stay for overnight, rest or just enjoy the holiday. In addition, hotels able to provide rooms for rent in general and also spoil the tourists with various facilities such as swimming pool, fitness center, spa, or beautiful natural scenery around the hotel environment. However, lately, the tourism industry, especially in the field of hospitality is being intensively offered a holiday alternative called timeshare (Harsono, 1994).

The timeshare program offers villa investment opportunities to a limited number of owners in which individual owners have the full opportunity to own villa property. Through the timeshare program, its members can purchase or

${ }^{\text {a }}$ Faculty of Law, National Education University, Denpasar, Bali, Indonesia 
rent exclusive lodging or resort accommodation that is provided in full and can do whatever they want to do with their vacation property and even rent it out to others with a certain time limit. Investment resort either in the form of villa or hotel by means of timeshare is relatively new in Indonesia, if measured the launch time period of the late 1990s, it means now the time is more than 10 years. Beyond the country, it was introduced in the 1960s in the Alps, France. During the holidays, many people rent a hotel there.

In its development, the timeshare investment business is not only applied to hotels, villas, condominiums, and homes but also in the areas of mutual funds, home sales, aviation, research, and technology and also in the communications sector. Healthy timeshare business is very beneficial for both the tourism industry and timeshare members. According to data from the Bali Culture and Tourism Office, in the tourism industry with the timeshare program, the owner or the lodger contributed 55\% of the local taxes. In addition, timeshare business helps to increase the income of the tourism industry by attracting more tourist arrivals (Tanjung, 1996). The advance of the tourism industry also contributes to the national economic recovery; based on the data recorded, foreign visitors to Bali in July 2017 have reached 592,046 people. This number has increased by 17.44 percent compared with a month earlier. The Bali Provincial Government is targeting the number of foreign tourists visiting Bali this year to reach 5.5 million people.

The distinguishing of the timeshare program is the owner will get double benefits, which are able to enjoy the holidays as well as doing investing. The investors of the timeshare program for property or villa business, for instance, able to enjoy the villa for free and on the other hand to gain profit as long as at that time villa is not being used, they can rent it (Widjaja \& Muljadi, 2003). Another advantage is that the properties that the investor has can holds (Right To Use/ RTU) that the price automatically raises from time to time. Timeshare also benefits for both parties, the developer no longer needs to find tenants or lodgers, and the owner does not need to take care of the villa because it is managed by the developer. In addition to the owner's benefit is they can use the villa facilities anytime (Subekti \& Citrosudibio, 1986). Another advantage of the timeshare program is the profit-sharing method based on revenue combinations, in which management receives $20 \%$ of the owner's net income as a management fee and the owner gets $80 \%$ as a result of the villa rental cost during the rented villa. However, timeshare business can experience losses for the owner in the case if they use villa continuously and gain no tenant to run the business so thus they could not get the income but must pay the management fee of $20 \%$. Basically, the timeshare program offers ownership either by trade (having Right to Use) or by the way of rent the property with special advantages as a common feature for timeshare program (Jaya, et al., 2018).

Some legal issues have been researched and studied for timeshare agreements are usually happened for Indonesian Law on Ownership that does not allow foreigners to own land directly on their behalf for lifetime purposes. On the other hand, the advantages or benefits for timeshare systems make it easier for a foreigner to own a villa with RTU/ Right to Use or rent in the long run (MLI, 2004).

Thus, it is very important to analyze or to study what is the legal regulation or law for timeshare program in Indonesia so that it can give clearer view for foreigners to have a villa or other property in Bali Province. Secondly, in the time of timeshare program with a fact that the villa owner hands over the management of his villa on the property development management, in this case, it needed to be studied for which side (between property development management or the owner) that will own or take a risk in case of force mejeur?

Therefore, in order to get answers for the problems mentioned above, it will be analyzed and will further explain on this study with titled "Villa Trading Contract With Rights To Use (RTU) On Time Share Business Program In Bali". It would be firstly elaborate for what is the legal basis or law for timeshare program which able to be owned for a foreigner in Indonesia (Muljadi \& Widjaja, 2004). And it will continue for the law that regulates the agreement with Right To Use as it becomes Formal Agreement. In addition, in this journal, the writer also will explain a law that might gain for the buyer of property still able to bind with the property developer or owner (Widjaya, 2003). Furthermore, this study will lastly explain general knowledge and how to regulate the risks for instance Force Majeure on the timeshare program (No, S. E. M. A. (3), 1963).

\section{Materials and Methods}

The research methodology describes the procedures for how a legal research is conducted. In the present study, the methods used i.e., formative legal research. A research is conducted or shown only on written regulations or other legal materials. A research is conducted with an approach to the field, in this case, in several villas in Bali to get documents and information as a basis for answering research problems. 
This research is descriptive which intends to provide data with the aim of strengthening existing theories. The data obtained is intended to provide an overview of the timeshare agreement and to strengthen the theory of agreements generally, the principles of agreement law, for example, the principle of consultation, the principle of freedom of contract and obligation, and the theory of sale and purchase agreement (Soekanto, 1990).

As a normative legal research, the data studied is secondary data. Secondary data is data obtained through literature study activities. Primary legal data is binding legal material. In this writing, the primary legal material used is the Civil Code, especially Book III on Engagement. Secondary legal data is legal material that provides an explanation of primary legal materials. Some books on agreement law, contract law, books on land rights and timeshare agreement documents were used. The tertiary legal data i.e., the material provides guidance and explanation of primary and secondary legal materials. Due to the timeshare contract is arranged in English, a dictionary is used as a tertiary legal material.

The selection of analytical events should always rely on the type and purpose of the study and the nature of the data collected. Due to this research is an iterative research type that uses secondary data and is descriptive in nature, the data obtained is processed qualitatively. Through qualitative descriptive analysis, all data both secondary data obtained from various literature and timeshare contract documents and primary data obtained from an informant through interviews, thorough and studied as a complete entity. After all data has been processed and analyzed, the deduction is deduced, in which general data, namely the provisions regarding the agreement as stipulated in the Civil Code and various experts' opinions on the agreement, are brought or compared with specific data, namely timeshare contract documents, and a conclusion is drawn (Rahman, 2003).

The research is conducted in the Villa with RTU in Bali. Measured achievement indicators and fishbone diagrams, in the first semester, identification of the problems that occurred in the sale and purchase contract of the villa with usufructuary rights in the timeshare program in Bali was carried out. In the second semester, a legal basis for the sale and purchase of a villa with RTU is conducted with the timeshare program in Bali (Sihombing, 2005).

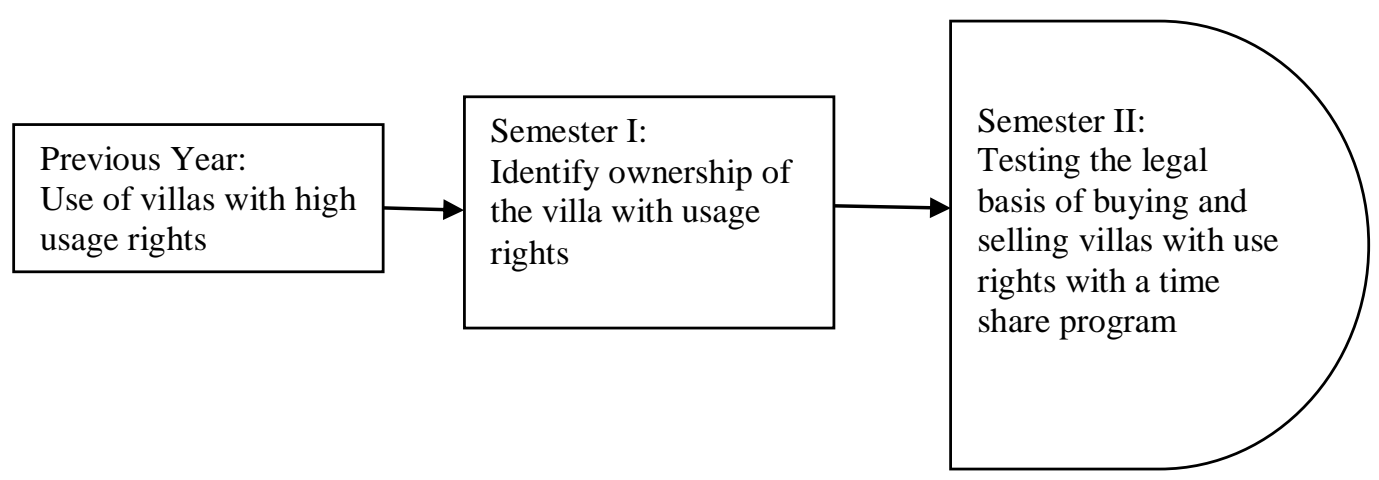

Figure 1. Fishbone diagram

\section{Results and Discussions}

\subsection{Indonesian Law: Timeshare Program can be Owned by WNA (Warga Negara Asing) or Foreigner}

The term timeshare was created in England in the early 1960's which is also known as the Share holiday home. In 1985 the term timeshare firstly appeared in Indonesia, especially in Bali. The timeshare community in Indonesia has established an association in 1994 under the name Indonesia Timeshare (ITA) supported by the government with the issuance of regulations concerning timeshare through the Ministerial Decree of Tourism, Post and Telecommunication (Menparpostel) No. KM.57/PW/102/MPPT96 then changed to Ministerial Decree of Tourism, art and culture No. 5413 / M-PSB / 98, dated December 13, 1998, and lastly revoked by Minister of Tourism and Culture No. Kep. 01/MNPK/2000. According to Oxford Advanced Learner, s Dictionary, Timeshare is:

"Arrangement in which a holiday home is owned jointly by several people who agree to use it each at different times of the year", the free translation means Timeshare is an agreement whereby a holiday house is owned jointly by several peoples who agree to use it respectively at different times over several years.

Sutrisni, N. K. E. (2018). Villa trading contract with right to use on timeshare business program in Bali. International Research Journal of Management, IT and Social Sciences, 5(6), 1-8. https://doi.org/10.21744/irjmis.v5n6.294 
Since the last decree of the Minister of Tourism and Culture, there are no laws and regulations that can be directly used for the timeshare business. The latest regulation aims to remove the policy from the Ministry of Tourism and Culture to the Ministry of Trade and Industry, which the decision has caused public controversy. In the land ownership law in Indonesia either in the regency, city, and province are regulated with the same rule. If a foreigner purchases land in Indonesia, their status is the Right To Use. So thus, the timeshare system makes it easier for foreign tourists to "own" private villa without having to look for land and take care of its license. A foreigner can own land by registering their land ownership marks as use rights. Right to use is a right that authorizes the use of other parties.

According to Article 39 of Government Regulation No. 40/1996 concerning Right of Use, Right of Use and Use Right on Land, the right to use may be owned by:

a) Indonesian citizen

b) Foreigners domiciled in Indonesia

c) Legal entities established under Indonesian law and domiciled in Indonesia

d) Department, Non-Departmental Government Institution and Local Government

e) Religious and social bodies

f) Foreign Legal Entity which has a representative in Indonesia.

g) Representatives of foreign countries representatives of international bodies.

Based on timeshare sale and purchase agreement of Hotel X, that timeshare program that acts as the owner of the right to use is Mr. Michael Rose a Foreign Citizen who is an Australian citizen but resides in Denpasar-Bali. Based on Article 39 of Government Regulation No. 40 of 1996 on the Right to Use of Business, Building Use Rights and use rights to land Mr. Michael Rose may use his villa with ownership status of villa rights (Nomor, P. P. (40), 1996).

\subsection{Trading Agreement with Use Rights in Timeshare Program is Formal Agreement}

Material Agreement is a contract that has been deemed to be born (legitimate) with the agreement reached between the two parties who entered into an agreement on several subject matters and what will become the object for the agreement. On the other hand, Formal Agreement is an agreement for which legitimacy by law is established, a certain formality. For example a grant agreement should be with a notary public. Informal agreements, agreements or oral agreements are solely between parties pledged solely between the parties that promise not to bear obligations on the party that promises to surrender something, to do or to do something or not to do or not to does something.

The sale and purchasing of villa with Right to Use in the timeshare program is an agreement, which the consensus type, which means that the sale and purchase agreement has been born as a legitimate (binding or legally enforceable) contract on the second point of agreement between the seller and the buyer regarding the principal elements of goods and the price of the concession nature is reflected from the regulation of article 1458 of the Civil Code which stipulates that "The Sale and Purchase has been deemed to occur between the two parties at once after they have reached an agreement on the goods and the price, even if the item has not been delivered and the price has not been paid. However, the trade process is also obligatory, meaning that the sale has not transferred "the right" to own but only grants the right and puts the obligation on both sides, namely giving the right to the buyer and demand the transfer of ownership of goods sold. The obligatory is reflected in Article 1459 of the Civil Code, which states "The property rights of goods sold do not transfer to the buyer, as long as the delivery is not done according to articles 612, 613 and 616."

According to Article 1475 of the Civil Code referred to as submission is a transfer of goods already. sold to. in the power and the possession of the buyer. In relation to the nature of the Obligatoire, then the sale and purchase agreement must be followed by leverage (juridical). In the case that the goods sold are immovable (e.g., villas and land), the legal act of transfer of rights is intended to transfer the rights to the land to another party forever (the legal subjects shall be obligatory as holders of land rights). The lands of the rights that can be obtained through the legal act of transfer of this right are Right of Owner, Right to Use, Right to Build, and Right to Use.

According to Article 37 of Government Regulation, on the registration of land, all legal acts aimed at transferring a plot of land of rights to another party shall be conducted in the presence of PPAT in charge of making the Deed, proving the existence of the legal act of transfer of such rights Article 37 of Government Regulation no. 24 on Land Registration is the provision of the implementation of Article 19 of the Basic Agrarian Law no. 5 the year 1960, which determines that the sale and purchase of land must be evidenced by a deed made before the PPAT and with the deed then the ownership of the land also moved (Indonesia, P. P. N., \& No, P. P. (24), 1997). 
Pursuant to and Article 19 of Act no. 5 of 1960, Article 37 of Government Regulation no. 24 on Land Registration, it is clear that the sale and purchase agreement on the land must be carried out under certain formalities (Formal agreement) (Indonesia, P. P. N., \& No, P. P. (24), 1997). Thus, it can be said that according to the civil law system applicable in Indonesia. Property rights do not switch, by themselves, but must be by submission. In this case, the surrender is the collection of objects that have been sold into power and belong to the buyer. The duty to surrender of property includes any conduct, which is legally required to transfer the property rights of the seller from the seller to the buyer. Therefore, the transfer of use rights to land by sale and purchase (except for sale and purchase by auction) must be done by deed made by P.P.A.T In addition, the transfer of use rights to the land of ownership must be done with written approval from the relevant owner. Based on the above considerations it is clear that the sale and purchase of land is a formal agreement Formality that must be met is that the sale and purchase of land must be made by deed P.P.AT.

On the other hand, the sale and purchase of land is a legal act that is bright and cash. Light means that the act of law is made in the presence of an authorized official witnessing the exercise or making of that legal action. Reference with cash means that with the completion of no law, is done with all the legal consequences. This means that such legal conduct cannot be undone again unless there is a defect regarding the ability and authority to act on that area of interest. In order for the transfer of such use rights to be properly exercised, an PPAT who will make the deed containing the transfer of right shall ensure the truth of the right of use to be transferred, and on the capacity and authority of the acting of those who will transfer and receive the transfer of right over the land. In the timeshare program in Bali, the owner makes a request for a right of use submitted in writing to the State Minister of Agrarian Affairs / Head of the National Defense Agency through the Office whose working area covers the location of the land concerned, until the owner makes a right to use application to the Office of the National Defense Agency where Villa resides. The petition contains the name, age, nationality, residence, and information about the wife who is still dependent. Subsequently, registration through PPAT (Land Deed Authority) authorized in this case is the office of PPAT and Notary attended by the parties performing legal acts concerned and witnessed by two witnesses Notary ie from the management and from the Office of PPAT and Notary the.

\subsection{Indonesian Law: The Buyer of Villa on Timeshare Program need still to be tangled with The Villa Owner}

In the sales and purchases agreement, with the transfer of ownership, the sale and purchase agreement is complete, there is no relationship between seller and buyer in timeshare program. Seller and Buyer/villa owner still have a legal relationship in villa agreement on management or services. The owner of the villa agreed to hand over the villa processing to the management. If the Villa Owner is not using the villas then the management can manage the Villa by leasing to others. In that relationship the villager will get compensation from the villa rental done by the management, and vice versa the villa owner has to pay villa maintenance fee if not being used because of the operational cost of owner and management ie villa owner and management, this is characteristic of buying and selling villa in the timeshare program, the villa owner buys as well as invests.

The existence of such an agreement is possible based on Article 1338 paragraph (1) of the Civil Code, a legallymade agreement, binding as the Act for the parties making it. With an emphasis on the word "all" that is in the face of the agreement. It is said that Article 1338 verse (1) is as if making a statement we are allowed to make any agreement and it will bind us as binding the law. The agreement is the basis of the binding of a treaty mapping about the power of the treaty, the same power as a law. Such powers are granted to all legally-established agreements.

\subsection{Risk Regulation in the Event of Force Majeure in Timeshare Program}

Force Majeure is unpredictable or might perceive as a good act, for instance, natural disaster. As a result of force Majeure then the problem risks arise, namely the obligation to bear the losses caused by a situation or events beyond the fault of one party. According to Article 1460 Civil Code in the sale and purchase agreement, if there is a state of force or force majeure, which overrides the object of the agreement then the risk of loss is the buyer's expense.

In terms of the timeshare program, the entire Property villa is borne by the insurance party covering it. Insurance is the responsibility of the seller. Namely, replace by providing a place to live in accordance with the villa owned with the same standards. The provisions governing force Majeure are covered by Article 4 of the contract of Sale and purchase of the Villa of the Substitution Residence, where it is said that "If the villa owner of the entertainment is

Sutrisni, N. K. E. (2018). Villa trading contract with right to use on timeshare business program in Bali. International Research Journal of Management, IT and Social Sciences, 5(6), 1-8. https://doi.org/10.21744/irjmis.v5n6.294 
uninhabitable for any reason, the promoter, in this case, the management upon the buyer's request, provide replacement accommodation in similar or larger apartments or provide one week replacement through X Exchange or Rci (Re Condominium International)".

\section{Conclusion}

Based on the principal issue of the proposed and also based on the theory of legal agreement then drawn the following conclusions:

a) Ownership of villas by Foreigners is possible with the right to use not property rights. And Foreign Citizen are domiciled in Indonesia according to Government Regulation No. 40 on Right of Use, Right of Use and Right to Use on land stating that "Those who have the right to use are: Indonesian citizens, Foreigners based in Indonesia, Legal Entities established under Indonesian law and domiciled in Indonesia, Departments, non-departmental government agencies and local governments, Religious and social bodies, Foreign legal bodies that have representatives in Indonesia, and Representatives of foreign countries and representatives of international bodies.

b) The sale and purchase of villa with use rights in the Time Share program is a formal agreement, meaning that for the legal villa sale agreement is not solely achieved by the agreement between seller and buyer concerning goods and price only (consensual), but by Law -The specified formality. As for what is meant by certain formalities in buying and selling villa is a necessity to be done notarial.

In the sale and purchase of villas with use rights through Time Share program, the situation is different. With the completion of the sale and purchase of the villa, with the payment of villa prices and the transfer of ownership rights over the villa, the buyer and the owner of the villa remain tied to the seller ie to the management or manager. Staying attached between buyers and sellers is a feature of the Time Share program. The villa owner handed over the management to the villa management. The owner obtains a number of advantages as stipulated in the agreement. In other words a villa buyer in the Time Share program while investing.

c) In the contract of sale and purchase of villa with use rights in the Time Share program, the arrangement of Force Majeure is explicitly not regulated, but this must be expressly stipulated in the sale and purchase agreement. In the agreement stated that the owner or management will provide replacement accommodation and the management has also insured villas so that if the villa is destroyed due to unforeseen circumstances, the insurer will take over the risk of various dangers that may occur.

\section{Suggestion}

In order to buy and sell a villa with Right to Use (RTU) in the timeshare program, it is considered need to construct an accessory agreement that made between management with the property or villa owner to strengthen and clarify the desired agreement, especially on disputes that may arise

Conflict of interest statement and funding sources

The author declared that she has no competing interest. The study was financed by personal funding.

Statement of authorship

The author has a responsibility for the conception and design of the study. The author has approved the final article.

Acknowledgments

The author would like to thank the journal team for their support, valuable time, and advice 


\section{References}

Harsono, B. (1994). Hukum Agraria Indonesia: Sejarah Pembentukan Undang-Undang Pokok Agraria, Isi dan Pelaksanaannya. Djambatan.

Indonesia, P. P. N., \& No, P. P. (24). tahun 1997 tentang Pendaftaran Tanah.

Jaya, I. G. N. A. A., \& Setiawina, N. D. (2018). Factors affecting customer using agent bank Laku Pandai program in Bali. International Journal of Social Sciences and Humanities, 2(2), 194-213.

MLI, S. (2004). Hukum Perjanjian Teori dan Analisa Kasus.

Muljadi, K., \& Widjaja, G. (2004). Hak-hak atas Tanah. Kencana.

No, S. E. M. A. (3). Tahun 1963 tentang Gagasan Menganggap Burgerlijk Wetboek Tidak Sebagai UndangUndang. Departemen Pendidikan Nasional Universitas Sebelas Maret Fakultas Hukum Jl. Ir sutami, (36).

Nomor, P. P. (40). Tahun 1996 tentang Hak Guna Usaha. Hak Guna Bangunan dan Hak Pakai Atas Tanah.

Rahman, H. (2003). Seri Keterampilan Merancang Kontrak Bisnis, Contract Drafting. Bandung: Citra Aditya Bakti.

Sihombing, I. E. (2005). Segi-segi hukum tanah dalam pengadaan tanah untuk pembangunan. Penerbit Universitas Trisakti.

Soekanto, S. Abdurahman. 1990. Metode Penelitian Suatu Pemikiran dan Penerapan.

Subekti, R., \& Citrosudibio, R. (1986). Kitab undang-undang hukum perdata: dengan... undang-undang perkahwinan. Pradnya Paramita.

Tanjung, A. (1996). Implikasi Undang-Undang Hak Tanggungan Terhadap Bisnis Properti. Jakarta: PT. Infomediatama Selaras.

Widjaja, G., \& Muljadi, K. (2003). Perikatan yang lahir dari perjanjian. Rajawali Pers, Jakarta.

Widjaya, I. G. (2003). Rai, Merancang Suatu Kontrak (Contract Drafting), Teori dan Praktik.

Sutrisni, N. K. E. (2018). Villa trading contract with right to use on timeshare business program in Bali. International Research Journal of Management, IT and Social Sciences, 5(6), 1-8. https://doi.org/10.21744/irjmis.v5n6.294 


\section{Biography of Author}

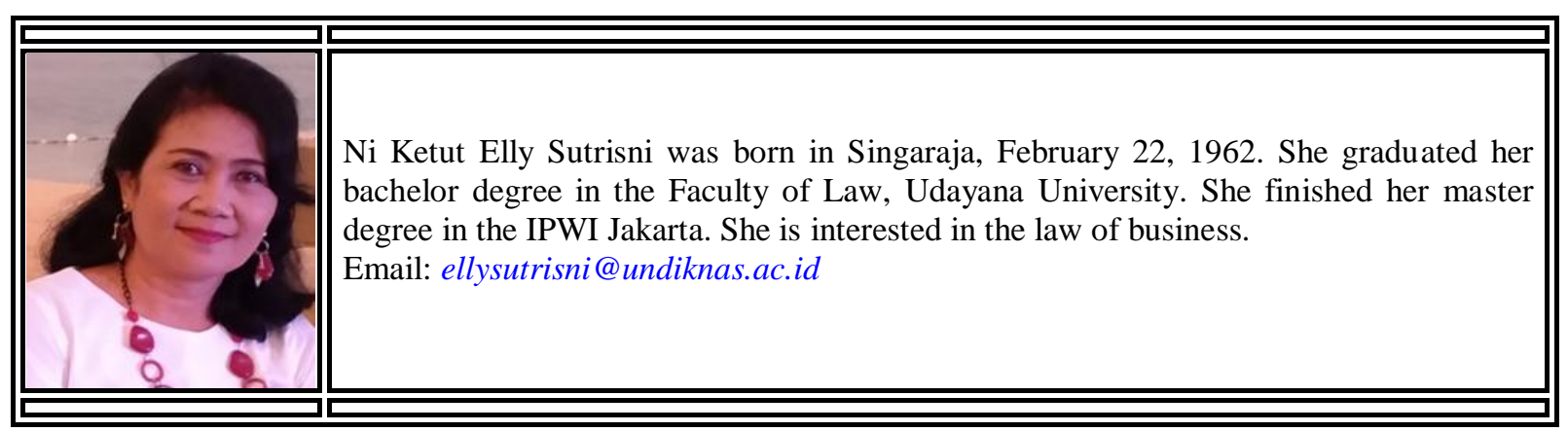

